$\begin{array}{lll}\text { Yayın Geliş Tarihi } & : & 07.09 .2017 \\ \text { Yayın Kabul Tarihi } & : & 28.12 .2018 \\ \text { Online Yayın Tarihi } & : & 09.01 .2019\end{array}$

Dokuz Eylül Üniversitesi

Online Yayın Tarihi : 09.01.2019

Iktisadi ve İdari Bilimler Fakültesi

Doi : 10.24988/deuiibf.2018332695

\title{
Asyalı Kadın Figürü ve Siyasetin Etkin Bir Öznesi: İndira Priyadarşini Gandi Mehmet Yahya ÇiçEKLI ${ }^{1}$ \\ $\ddot{O}_{z}$
}

Bir Hint siyasetçi olan İndira Priyadarşini Gandi Asyalı bir kadın siyasetçi figürü olarak uzun süre Hindistan'ın başbakanlığını yapmıştır. İlk bakışta yenilikçi ve inkılapçı bir siyasetçi görünümü arz etmektedir. Ancak ne yazık ki Türkiye Türkçesindeki akademik yazında onun siyasal duruşuna, uygulamalarına ve mücadelesine ilişkin incelemelere hatta yaşam öyküsüne dair temel bilgilere bile ulaşmak mümkün değildir. Oysa İndira; gerek yeni bağımsızlığını kazanmış bir eski sömürge ülkesini kendi ayakları üstünde tutmaya ve yükseltmeye çalışan bir yönetici olarak, gerekse tabularl yıkan fakat kültürel değerlerine bağlı bir modernist olarak son derece ilgi çekici bir öznedir. Farklı çalışmalara kaynaklı etmek ve karşılaştırmalı incelemelere imkan tanımak üzere bu çalışmada genel bir çerçeve çizilmesi ve bir değerlendirme ortaya konulması amaçlanmıştır. Bunun için öncelikle başvuru yapılabilecek temel kaynaklar tespit edilmiş, ardindan farkl kaynaklardan mukayeseli olarak İndira GANDI'nin yaşam öyküsü damıtılmaya çalışılmış, tespit edilen olgular tüm yaşamını kapsayan üç dönem halinde sunulmuştur. Her biri temel kaynak sayllabilecek farkl kaynakların birleştirilmesi ile sağlam bir zemin oluşturulmaya çalışılmıştır. Sunulan olgular incelenmiş ve yorumlanmış, böylece bu yaşam öyküsü çerçevesinde öne çılkan başlıca yönler, temel nitelikler ve siyasal mücadelesinin bir takım sonuçları ortaya konulabilmiştir. Kadın hakları da dahil olmak üzere öncelik verdiği konularda yaptı esaslı çalışmalar dikkat çekici bir tablo oluşturmuştur.

Anahtar kelimeler: Kadın siyasetçi, kadın başbakan, Asyalı kadın figürü, Hindistan, İndira GANDI.

\section{Asian Woman Figure And An Active Subject Of Politics: Indira Priyadarshini Gandhi Abstract}

An Indian politician, Indira Priyadarshini GANDHI, as an Asian woman politician figure, had been the prime minister of India for a long term. At first glance, she presents a progressive and reformist politician image. Unfortunately, in academic literature in Anatolian (Istanbul) Turkish it is not possible to reach reviews about her practices, political standing, and struggle. Nevertheless, Indira is an attractive subject, both as a ruler to make a former dominion which just achieved independence stand on its own feet and a modernist who breaks taboos while at the same time sticking to cultural values. The aim of this study is to provide a reference to different works and a possibility to comparative studies by drawing a perspective and state an evaluation. To achieve these, at first basic sources for reference are identified, then Indira GANDHI's life story was refined comparatively from different sources, and fixed facts are presented over three periods that cover all her life. By interlacing different sources, where each could be considered a basic reference, it was aimed to pave a solid ground. Presented facts are reviewed and interpreted so that it was possible to put forth a number of outcomes of her political struggle, main and prominent aspects and basic characteristics in the scope of this life

\footnotetext{
${ }^{1}$ Yasama Uzmanı, Türkiye Büyük Millet Meclisi
} 


\section{M.Y. ÇİÇEKLİ}

story. Her principal works in fields she gave priority, including women's rights, made up an interesting panorama.

Keywords: Woman politician, woman premier minister, Asian woman figure, India, Indira Gandhi.

\section{GíRiş}

$\mathrm{Bu}$ çalışmanın konusu, yaygın olarak ilk adı ve evlilik soyadıyla tanınan dünya çapında ünlü bir Hint siyasetçidir. İndira Priyadarşini Gandi² (19 Kasım 1917 - 31 Ekim 1984) Dünya'da Başbakan olan ikinci kadındır³. Dünya'da en uzun süre başbakanlık yapan kadın sıfatı da henüz ona aittir. Bir sömürge ülkede yetişmiş olmakla birlikte, aydın ve siyasetçi olarak "Batı" mefhumuna eleştirel yaklaşmıştır. Hayatı ve politikalarına bakıldığında milliyetçi ve sosyalizme yaklaşan halkçı tutumları göze çarpmaktadır.

Evlilik soyadı nedeniyle, ne kendisinin ne de eşinin akrabalığı olmamasına rağmen yaşam öyküsü hakkında ayrıntılı bilgi sahibi olmayanlar kendisinin Mahatma Gandi'nin kızı veya akrabası olduğunu zannetmektedir (Lyon, 2008: 64). Varlıklı ve toplum içinde önde gelen bir ailenin mensubu olarak başladığ 67 yıllık yaşamının neredeyse tamamı mücadeleler içinde geçmiştir. Genç yaşlarından itibaren Hindistan'ın bağımsızlığı için çalışmış daha sonra da Başbakanlık dâhil olmak üzere çeşitli siyasal mevkilerde yer almıştır. Adeta tüm ömrünü ülkesine ve milletine vakfetmiştir. Tarihe Hindistan'ın ilk kadın başbakanı olarak geçmiştir. Bağımsız Hindistan'ın üçüncü başbakanıdır. 1999 yılında BBC'nin yaptığı bir ankette (BBC, 1999) son bin yılın en büyük kadını seçilmiştir.

$\mathrm{Bu}$ çalı̧̧manın iki amacı vardır. Birincisi, farklı kaynaklardan taranarak özetlenmiş kısa yaşam öyküsünü Türkçe akademik literatüre kazandırmaktır. Farklı kaynaklara başvurarak görece daha nesnel bir tablo oluşturulması gözetilmiştir. İkincisi ise, onun

\footnotetext{
${ }^{2}$ Evlilik öncesi soyadı Nehru'dur. Hintçe yazımı; इन्दिरा = İndira, प्रियदर्शिनी = Priyadarşini, गाँधी $=$ Gandi, नेहरू $=$ Nehru şeklindedir.

3 Dünya'da başbakan olan ilk kadın Sri Lanka'lı Sirimavo Bandaranaike'dir (Kadın başbakan ve cumhurbaşkanlarıyla ilgili bir derleme için bkz. Opfell, 1993).
} 
özellikle siyasal yaşamında önem arz eden eylem ve kararlarına hâkim olan genel nitelik ve ilkelerin tespit edilmesi ve tartışılmasıdır. Bu genel nitelik ve ilkeler tespit edilirse onun siyasal mücadelesinin özü ortaya çıkacaktır. Böylece Hindistan ve dünya tarihindeki yeri değerlendirilebilir.

Güncel Türkçe literatürde, gazete haberleri dışında doğrudan İndira Gandi’yi konu alan akademik veya edebi hiçbir kitap veya makale bulunmamaktadır ${ }^{4}$. Tek bir istisna dışında hiçbir yayında İndira Gandi konu alınmamıştır. Yalnızca Ali Çimen’in yazmış olduğu Tarihi Değiştiren Kadınlar (Timaş, 2008) adlı kitap içinde bir bölüm ona ayrılmıştır. Ancak bu kitap incelendiğinde içinde hiçbir akademik atıf, kaynakça, okuma listesi bulunmadığı görülmektedir. Böylece kaynağı veya neye dayandığı belli olmayan bir metin olduğundan bu çalışmada söz konusu yayından hiç istifade edilmemiştir.

Bir kadın olarak tarihe geçtiği vasıflarının yanında, Hindistan'ın kaderinde oldukça uzun bir süre için (1966-1977 ve 1980-1984) en çok söz sahibi olan insan konumunda olması, onun biyografisini 20. yüzyılda tarihe mâl olmuş kişiler arasında ön plana çıkarmaktadır. Bu bakımdan Türkçe literatürde onunla ilgili eser bulunmaması bir eksiklik olarak görünmektedir. Bu çalışma İndira Gandi'nin kısa biyografisini tek bir kaynağa bağlı kalmadan karşılaştırmalı bir yaklaşımla Türkçe olarak aktarması ve incelemesi bakımından özgün ve önemli bir girişimdir.

Veri toplama yöntemi olarak mümkün olduğu kadar çok sayıda kaynağa ulaşılması ve yaşam öyküsünün tüm bu kaynaklardan yararlanılarak özetlenmesi arzu edilmiştir. Zira böylece daha nesnel bir tasvire ulaşllabileceği değerlendirilmiştir. Yaşam öyküsü derlenirken çok sayıda kaynağın yan yana getirilmesi bir kaynaktaki eksik parçaların başka kaynaktan tamamlanabilmesi fırsatını sunmuştur. Yapılan İngilizce kaynak

\footnotetext{
${ }^{4}$ Ansiklopediler bu değerlendirmenin dışında tutulmuştur.
} 


\section{M.Y. ÇİÇEKLİ}

taramasında hem Hindistan menşeli hem de başka yayınlara ulaşılmıştır ${ }^{5}$. Böylece hem kendi ülkesinden, hem de dişarıdan farklı bakış açılarına ulaşılmıştır. Bu çalışmanın kaynakçası da, İndira Gandi’nin yaşamıyla ilgili gelecek çalışmalarda yararlanılabilecek zengin bir literatür taramasının sonuçlarını içermektedir. $\mathrm{Bu}$ araştırmaya kaynak olan tüm eserlerin arasında özellikle Axelrod (1999) ile Dommermuth-Costa'nın (2001) eserleri ve İndira Gandi'nin (2013) otobiyografisi temel kaynak niteliğindedir. Bununla birlikte, bu çalışmalardan herhangi birinin temel alınarak takip edilmesi yerine, mümkün olan en geniş şekilde diğer kaynaklardan da yararlanılarak hiçbirinin etkisinde kalmadan özgün bir derleme ve bakış oluşturulmaya çalışılmıştır.

Toplanan verilerin tasnif edilerek aktarılmasında yöntem olarak, İndira Gandi'nin doğumundan 25 yaşına kadar olan dönem (1917-1942) Erken Yaşamı; 25-39 yaşlarına karş1lık gelen dönem (1942-1956) Gençlik Dönemi ve Erken Siyasal Çalışmalart; siyaseten yüksek konumlarda yer almaya başlamasından ölümüne kadar olan dönem de (1956-1984) Siyaset Yaşamı başlıkları altında sunulacaktır. Farklı kaynaklara yapılan başvurulara rağmen açıklığa kavuşmayan yönler ise gri alanlar başlı̆̆ı altında ayrıca incelenecektir.

“Uzun bir ömrü önemsemiyorum. Bu tarz şeylerden korkmam. Bu millete hizmet ederken hayatımı kaybetmeyi umursamam. Eğer bugün ölürsem, kanımın her damlası milleti kuvvetlendirecektir. ${ }^{6 "}$ diyebilen, cesur ve idealist bir kadının yaşam öyküsünü araştırmak ve incelemek, akademik bir çalışma olarak son derece ilgi çekici olmuştur. Günahları ve sevaplarıyla İndira Gandi, tarihi önemi tartışılamayacak bir kadındır.

\footnotetext{
${ }^{5}$ Hindistan'da yaygın olarak İngilizce yayın yapılması bu çalışmada ayrıca Hintçe tarama yapılmamasının eksikliğini telafi etmiştir.

${ }^{6}$ Suikaste kurban gitmesinden birkaç gün önce söylediği sözlerdir (Smith, 1984).
} 


\section{ERKEN YAŞAMI (1917-1942)}

Hindistan'ın bağımsızlığına gönül vermiş, üst-orta veya üst sınıftan ${ }^{7}$ gelen (Frank, 2002, s.6) ve Hindistan siyasetine damgasını vurmuş Nehru ailesine mensuptur. Bayan Kamala ve Hindistan'ın ilk başbakanı olan Bay Cevahirlal'ın ${ }^{8}$ tek çocuğu olan İndira, 19 Kasım 1917 tarihinde Hindistan'ın Allahabad şehrindeki, varlığını bugüne dek sürdüren Anand Bavan köşkünde dünyaya gelmiştir. İndira'nın dünyaya gözlerini açtığı Allahabad şehri tarihi öneme sahiptir. İndira’nın büyükbabası Molilal Nehru da önde gelen bir milliyetçi ve siyasetçiydi. Ailesinin ve aile çevresinin etkisiyle İndira erken yaşlarında kendini siyasetin içinde bulmuştur. İndira 10-11 yaşlarındayken, Allahabad'da olmadığ 1 dönemde babası ona tabiat, tarih, insan toplulukları ve Hindistan ile ilgili bir dizi öğretici mektup yazmıştır . Bu mektup akışı ilerleyen yıllarda da devam etmiştir ve babasının İndira'ya yaklaşımının siyasal konuları da kapsayan bir "öğreticilik" içerdiğine işaret etmektedir"10.

İndira 12 yaşında "Maymun Tugayı" adlı çocuk teşkilatını kurmuştur. Burada çocuklar, Hindistan Milli Kongresi’ndeki ebeveynlerine yardımcı olmaya çalışmış ve İngiliz Polisi üzerinde casusluk da dâhil olmak üzere çeşitli çalışmalar yapmışlardır. (Axelrod, 1999)

Öğrenimini Hindistan ve Avrupa'da görmüştür. Yükseköğrenimine ilk kez Santiniketan ${ }^{11}$ adlı Hint üniversitesinde başlamıştır. Ancak 1935'te tüberküloz hastası olan annesiyle birlikte Avrupa'ya gitmişlerdir (Axelrod, 1999). 1936'da İngiltere'de

\footnotetext{
${ }^{7}$ Nehru Ailesinin toplumsal statüsüne ilişkin çeşitli göstergeler olsa da, 1910 ve 1920 'lerin Hindistan toplumu ve özelde Allahabad bölgesi için genel bir tablo çizmeden bu tasnifin yapılması zordur ve ancak ayrı bir çalışmanın konusu olabilir.

8 İngilizce kaynaklarda "Jawaharlal" olarak geçmektedir.

9 Cevahirlal'ın bu mektupları 1929'da kendisi tarafından kitaplaştırılarak yayımlanmıştır (Nehru, 1929).

${ }^{10}$ Cevahirlal'ın devam eden mektupları daha sonra tekrar kitaplaştırılarak yayımlanmıştır (Nehru, 1934).

$11 \mathrm{Bu}$ okul daha sonra Visva-Bharati adını almıştır ve bugün de faaliyetlerini sürdürmektedir. Bakınız: visvabharati.ac.in, 2012.
} 


\section{M.Y. ÇİÇEKLİ}

Oksford Üniversitesine (University of Oxford) bağlı Somerville Kolejine başvurmuştur. Üniversite sınavına hazırlandığı süreçte annesinin sağlık sorunları kötüye gitmiştir. Akciğerlerindeki rahatsızlı̆̆1 1935'te son derece ilerlemiştir. Uzun süredir hastalıkla mücadele eden ve sanatoryumlarda kalan annesi son bir umut olarak İsviçre'ye nakledilmiş fakat 1936 yılında burada yanında eşi ve kızı varken hayatını kaybetmiştir. (Somervill, 2007: 35; Frank, 2002: 100 vd.) Bu acının etkisiyle üniversiteye giriş sınavını ilk kez denediğinde başarısız olmuştur. Sınavı geçinceye kadar özel Badminton Yatılı Kız Okulu'nda ${ }^{12}$ bir kaç ay kadar kalıp eksiklerini tamamlamaya çalışmıştır. (Frank, 2002: $115 \mathrm{vd}$.)

Daha önceden ailecek tanıştıkları Firuze Gandi, 1933 yılında kendisine evlenme teklif etmiş, ancak bu teklif İndira ve annesince, daha çok genç olduğu öne sürülerek reddedilmiştir (Frank, 2002: 81). İngiltere'de kaldığı süre boyunca, London School of Economics'te öğrenim görmekte olan Firuze ile görüşmeye devam etmiştir. İngiliz İşçi Partisi siyaseti ve sosyalizm ile ilgilenmişlerdir. (Somervill, 2007: 36)

Avrupa'da kaldığı sürece kendi sağlık sorunlarıyla da uğraşmıştır. İngiltere'de kaldığı sürede öğrenimine ara verip İsviçre’ye giderek tedavi olması gerekmiştir. Tarih, siyaset bilimi ve iktisat alanlarında çok başarılı olmuş fakat Latince derslerinde problem yaşamıştır (Somervill, 2007: 36). Okulu bitirmemiş olsa da, Oksford Üniversitesi sonradan İndira Gandi'ye onursal diploma vermiş ve 2010 yılında onu en önemli 10 Asyalı mezunundan biri seçmiştir (ox.ac.uk). 1941 y1lında üniversite eğitimini yarım bırakıp Oksford'dan kesin olarak ayrılarak Firuze ile birlikte uzun bir gemi yolculuğuyla Hindistan'a dönmüştür. Hindistan'a döndüğü sırada babası Cevahirlal hapistedir (Somervill, 2007: 168). Hindistan'a döndükten sonra 23 Mart 1942 tarihinde evlenmiştir. (Axelrod, 1999)

İndira'nın yaşamında ve düşünce dünyasında Mahatma Gandi'nin önemli bir yeri vardır. İndira, Mahatma GANDİ ile daha küçük bir kızken tanışmıştır (Dommermuth-

${ }^{12}$ Okul ve ünlü mezunları için bakınız: badmintonschool.co.uk, 2012. 
Costa, 2001: 20). Gerek İndira, gerekse eşi Firuze, Mahatma Gandi'den derinlemesine etkilenmişlerdir. İndira'nın babasının da Mahatma Gandi ile yakın bir ilişkisi vardır, ilerleyen yıllarda babasının özel yardımcısı olan İndira da babası adına sık sık Mahatma Gandi'yi ziyaret etmiştir (Dommermuth-Costa, 2001: 48). Hindistan'daki kast sistemi ve Firuze'nin Müslüman olması, başta İndira'nın babasının evliliklerine karşı çıkmasına neden olsa da, Mahatma Gandi bu evliliği önemsemiş ve desteklemiştir (Gandhi, 2013: 49).

\section{GENÇLİK DÖNEMİ VE ERKEN SIYYASAL ÇALIŞMALARI (1942-1956)}

1942'nin Eylül ayında, bir gösteride halka hitaben konuşma yaparken tutuklanmıştır. 1943 yılının Mayıs ayında serbest bırakılmıştır. 20 Ağustos 1944 'te ilk çocuğu olan Rajiv Gandi'yi doğurmuştur. İkinci oğlu Sanjay ise 14 Aralık 1946 tarihinde doğmuştur. $\mathrm{Bu}$ sırada ülkenin bağımsızlık süreci hızlanmıştır (Axelrod, 1999). Şubat 1947'de Başbakan Clement Attlee İngiltere Hükümetinin Haziran 1948'e kadar Hindistan'a tam özyönetim hakkı vereceğini açıklamıştır (Romein, 1962: 357). Hindistan Genel Valisi Louis Mountbatten yetki devrini öne almıştır (Read, 1999).

14 Ağustos'u 15 Ağustos'a bağlayan gece Cevahirlal Nehru tarihin en önemli konuşmalarından biri sayılan ünlü konuşmasını yapmıştır (guardian.co.uk). 15 Ağustos 1947'de Hindistan parlamenter hükümet sistemini benimseyip bağımsızlı̆̆ını kazanmıştır. Cevahirlal ise Hindistan'ın ilk başbakanı olmuştur. Babasına destek vermek isteyen İndira, çocukları ile birlikte Yeni Delhi’ye taşınmıştır. Firuze ise siyasal çalışmaları nedeniyle Yeni Delhi'ye taşınmadan önce bir süre daha Laknov'da kalmıştır (Axelrod, 1999). İndira burada bir danışman ve özel kalem gibi babası Cevahirlal'ın işlerini ve görüşmeleri yürütmüştür. Bu sırada resmi bir görevi olmasa da siyaset çevrelerini çokça tanımış ve tanınmıştır.

$\mathrm{Bu}$ dönemde, annesinin yokluğunda babasının yardımcısı olarak, Hindistan Başbakanının yakın çevresinde siyasete dair önemli deneyimler kazandığı anlaşılmaktadır. 1950 yılında Soğuk Savaşın başlangıcında Hindistan uluslararası 


\section{M.Y. Ç̇ÇEKLİ}

tarafsızlık ilan ettiğinde (Dommermuth-Costa, 2001: 68; Gandhi, 2013: 74) ve ülke hayatını etkileyen diğer önemli gelişmelerde İndira babasının yardımcısı olarak siyasal gelişmeleri yakından izleyebilmiştir. 1952 yılında eşi Firuze milletvekili seçilmiş ve böylece o da Yeni Delhi'ye gelerek İndira'nın yanında olabilmiştir (DommermuthCosta, 2001: 69). Gerek eşinin gerekse babasının siyasette etkin olarak yer almasının İndira'nın bir siyasetçi olarak yetişmesinde önemli etkisi olduğu değerlendirilebilir.

Başbakan'ın özel yardımcısı olarak edindiği deneyimler, 1953 yılında 36 yaşında Çin Halk Cumhuriyeti (ÇHC) ve Sovyet Sosyalist Cumhuriyetler Birliği'ni (SSCB) babasının temsilcisi olarak ziyaret etmesiyle taçlanmıştır. 1955 yılında, bu sefer babasıyla birlikte olmak üzere tekrar SSCB'ye resmi ziyarette bulunmuştur. Yine 1955 yılında parti içinde de daha etkin görevler almıştır (Dommermuth-Costa, 2001: 70-71; Gandhi, 2013: 75-76).

\section{SIYYASET YAŞAMI (1956-1984)}

1956 yılında Kongre Partisinin en önemli karar alma organı olan Çalışma Komitesinin üyesi olmuştur. Git gide siyasetle daha içli dışlı olsa da, 1957 seçimlerinde milletvekili adayı olmamıştır (Frank, 2002: 236-241). İndira 1959 yılında Kongre Partisi'nin başkanı olmuştur, ancak bir yıl kadar sonra bu görevi bırakmıştır (DAS, 2001: 26; Axelrod, 1999). 1964 y1lının Ocak ayında Cevahirlal bir kalp krizi geçirerek kötüleşmiş ve Mayıs ayında da bir başka kalp krizi neticesinde hayatını kaybetmiştir (BBC News). Demokrasiye inanan Başbakan yerine bir veliaht veya halife bırakmamıştır. Kurulan Lal Bahadır ŞASTRİ hükümetinde Bilgi ve Yayıncılık Bakanı olarak İndira görev almıştır. 10 Ocak 1966'da ŞASTRİ hayatını kaybedince 355 oya karş1 169 oyla yeni kurulan hükümette başbakan olmuştur (Dommermuth, 2001: 89; Gupta, 2003: 121). Başbakan olduktan sonra, kuraklık ve açlık gibi sorunlarla karş1 karşıya kalmıştır. (Dommermuth, 2001: 90) Yurt gezilerinde kitlelerle kaynaşmıştır. Bilhassa güçsüz ve fakirlerle yakınlaşmıştır. (Axelrod, 1999) 
1967 Seçimlerinde, partisinin sandalye sayısı 297'ye düşmüştür ${ }^{13}$. Bu dönemde ülkesinin tarımını kendine yeter hale getirmek için "Yeşil Devrim" olarak bilinen çalışmalara başlamıştır. Ürün çeşitliliğinin arttırılması, gübre kullanımı ve tohum ıslahı gibi konularda çalışmalar yapılmıştır (Heitzman, 1995). 1966 yılında Hindistan ekonomisi \%3,7 küçülmüştür ve oldukça zor durumdadır (Rosser, 2004). Buna rağmen İndira sonraki yıllarda ekonomiyi düzlüğe çıkartabilmiştir (Nayak, 2010: 8-9). 1969'da parti sağ ve sol olarak ikiye bölünmüştür. Sağ kanadın başını Morarji DESAİ çekerken, İndira'nın başında bulunduğu sol kanat diğer sol partilerin desteğiyle iktidarda kalmıştır. Yoksullukla kesin olarak mücadele etmek isteyen İndira, toprak reformu çalışmalarına girişmiş ve bankaları millileştirmiştir. (Axelrod, 1999; Heitzman, 1995; Muralidharan, 2009: 4)

İndira, "Yoksulluk Bitsin"14 sloganıyla girdiği 1971 seçimlerinden kesin bir galibiyetle çıkmıştır (IPU, 1971). Bu galibiyetin ardından kömür, demir, bakır, rafineri, tekstil alanlarında da millileştirmeye gitmiştir (Dash, 2000). Doğu Pakistan (Sonraki Bangladeş) ve Batı Pakistan arasında 1971'de çıkan iç savaş Hindistan'1 doğrudan etkilemiştir. Ülke, Doğu Pakistan'dan kaçan milyonlarca mültecinin akınına uğramıştır. Pakistan tarafından Hindistan'daki sekiz havaalanının vurulması sonrası bu iç savaşa dâhil olmuştur. Hindistan iki hafta içinde zafer kazanmıştır ve Doğu Pakistan'ın yerine Bağımsız Bangladeş devleti kurulmuştur (Dommermuth, 2001: 100; Kulke, 2004: 359, Quereshi, 2002). Bu savaşta Hindistan'ın yanında SSCB yer alırken Pakistan'ın yanında ABD ve ÇHC yer almıştır.

Savaştan sonra Hindistan bölgesel bir güç olarak kendini ispatlamıştır. Daha öncesinde, ÇHC'nin nükleer denemeleri neticesinde 1967'de İndira nükleer silah geliştirilmesi talimatını vermiştir. 1974 yılında ilk başarılı deneme yapılmıştır (nuclearweaponarchive.org, 2001). Hindistan'ın ilk nükleer silahının üretilmiş ve

\footnotetext{
${ }^{13} \mathrm{O}$ dönemde Hindistan Halk Meclisi (Lok Sabha) 525 sandalyelidir.

14 "Yoksulluk Bitsin" adı bu metnin yazarının tercümesidir, aslı; "Abolish Poverty".
} 


\section{M.Y. Ç̇ÇEKLİ}

denenmiş olmasının yanında İndira'nın iktidarında yörüngeye uydu da yerleştirilebilmiştir. 1973 yılında Londra Sunday Times gazetesi tarafından “Dünya'nın en güçlü kadını” ilan edilmiştir (Axelrod, 1999). İndira'nın iktidarı boyunca Hindistan'ın silah ihtiyacını karşılamada en önemli dış kaynak Sovyetler olmuştur ve ikili ticaret de gelişme göstermiştir (Racioppi, 1994: 65). Hindistan'ın Sovyetlerle ilişkileri geliştikçe ABD ile olan ilişkileri gerilemiştir. İndira, Arap - İsrail çatışmalarında Filistin'e sürekli destek vermiştir (Gupte, 2012: 5).

İndira, babasının döneminde medeni hukuk alanında yapılan inkılapları; kadınların miras ve sükna (ikamet) haklarının iyileştirilmesi gibi çabaları devam ettirmiştir. Kadın ve erkeklere eşit ücret uygulaması İndira'nın sosyal inkılapları arasında öne çıkmaktadır (Sarkar, 2008: 489 vd.). Yurt gezilerinden birinde, "Hariciler" denilen en alt kasta mensup bir grup kadının daha üst sınıftan erkeklerce tecavüze uğramaları olayıyla ilgilenmiş, mağdur kadınların yanında yere oturup onların başından geçenleri dinlemiştir (Smith, 1984). Doğanın korumasına da önem veren İndira, 1968 yılında kaplan kürkü ihracatını ve 1970 yılında kaplan avlanmasını yasaklamıştır. 1972 yılında Dünya Doğayı Koruma Vakfı $(W W F)$ ile birlikte hazırlanan ve bir sonraki yıl uygulamaya geçirilen "Kaplan Projesi” ile ülkesinde yalnızca kaplanları değil tüm doğal yaşamı koruma altına almayı hedeflemiştir ${ }^{15}$.

1975 yılında Allahabad Yüksek Mahkemesinde yapılan yargılamada hâkim Jagmohan Lal Sinha ${ }^{16}$, 1971 seçimlerinde kampanyasını yürütürken resmi araçlar ve devlet memurlarını kullandığı gerekçesiyle İndira'yı suçlu bulmuştur. Kararda milletvekilliği geçersiz ve hükümsüz ilan edilmiştir ve 6 yıl boyunca seçimlere girmekten yasaklanmıştır (Palmer, 1976; Noorani, 2008). Bunun üzerine, Hindistan Anayasasının 352. maddesi uyarınca İndira'nın teklifi üzerine devlet başkanı

\footnotetext{
15 Ayrıntılar için bakınız: “Project Tiger" http://www.lairweb.org.nz/tiger/project.html “Tigers” http://www.seaworld.org/animal-info/info-books/tiger/conservation.htm

16 Kısa özgeçmişi için bakınız: http://www.allahabadhighcourt.in/Judges/exjudges/JLSinha.htm
} 


\section{Dokuz Eylül Üniversitesi İktisadi ve İdari Bilimler Fakültesi}

Fakhruddin Ali Ahmed olağanüstü hal ilan etmiştir. 1977'de seçimler yapılana kadar ülkede olağanüstü hal ve başbakanın olağanüstü yetkileri devam etmiştir. Bu durum Hindistan demokrasinin geleceği bakımından soru işaretleri yaratmıştır ve oldukça eleştirilmiştir (Somjee, 1977).

İndira, olağanüstü hal ilanını, partisinin sosyalist bir amac1 olduğunu söyleyerek savunmuştur ve bu dönemde toprak dağıtımı ve yoksulların borçlarının yeniden yapılması gibi birtakım önlemlerle refahın yeniden dağıtılmasına girişmiştir (Jaffrelot, 2003: 131-142). Bu süreçte ücretler dondurulmuş, toplant1 ve gösteri, grev, basın özgürlüğü gibi haklar askıya alınmıştır. Hükümetin nüfus planlaması uygulamaları neticesinde "zorla kısırlaştırma" iddiaları sert protestolara yol açmıştır (Axelrod, 1999). Bu dönemin sonunda, 1977'de yapılan seçimlerde İndira iktidarı kaybetmiştir. Milli Kongre Partisi’nin 30 yıl süren iktidarı böylece sona ermiştir (IPU, 1977).

1980 yılında yapılan genel seçimlerde İndira'nın partisi 351 ve seçim müttefikleri de 23 sandalye kazanarak, seçime gidilen 525 sandalyeden 374'ünü elde etmek gibi büyük bir zafere ulaşmıştır (IPU, 1980). Bir önceki (1977) seçimler sonucunda Başbakanlığı bırakmak zorunda kalmış olan İndira, koltuğundan sükûnet içinde itirazsız ayrıldığı için itibarını korumuş ve iktidardan düşmesinin üstünden henüz üç yıl geçmişken gelen 1980 galibiyetiyle tekrar Başbakan olabilmiştir (Axelrod, 1999). Bir önceki yıl (1979) Hindistan tarihinin en kötü ekonomik manzarası ortaya çıkmış ve ekonomi \%5,2 küçülmüştür (Kelly, 2010). İktidara yeniden gelen İndira Hükümeti devraldığı bu kötü ekonomik tablo karşısında altıncı beş yıllık ekonomik planı hazırlamıştır ve yıllık ortalama \%5,2'lik bir büyüme hedeflemiştir. Bu plan yıllık ortalama \%5,7'lik büyümeyle Hindistan tarihinin en başarılı 5 yıllık planı olmuştur (Dash, 2000: 114).

1983 yılında, Hükümetin Pakistan'dan gelmiş Müslüman göçmenlere oy hakkı tanımasıyla Hindular ve Müslümanlar arasında çatışmalar çıkmıştır. Bu olaylar karşısında İndira, yüzyıllardır süren ve ülkeyi bölen dinsel ayrılıkları eleştiren 


\section{M.Y. Ç̇ÇEKLİ}

konuşmalar yapmıştır (Axelrod, 1999). Aynı sıralarda bir tür Sih hareketi yükselmiştir. Sihler için ayrı bir devlet kurmak isteyen bir grup silahlı hareketlere girişmiştir. 1983 'te ayrılıkçı asi Jarnail Singh Bhindranwale ve silahlı takipçileri, Sihler için en kutsal mabed olan Altın Tapınak'a yerleşerek silah ve cephane toplamaya başlamışlardır (Marty, 2004: 454). Bu hareketi durdurmaya yönelik girişimler sonuçsuz kalınca İndira ordu birliklerine Altın Tapınak'a girme emri vermiştir. Çok ünlü Mavi Yıldız Harekâtı sonucunda Tapınak zarar görmüş ve ayrılıkçılarla birlikte siviller de ölmüştür (Ahmed, 1999: 130; ayrıca bakınız Brar, 1993).

$\mathrm{Bu}$ askeri operasyon sonucunda Sihler arasında yaygın bir tepki oluşmuştur. $\mathrm{Bu}$ kargaşa ortamında istihbarat teşkilatı da dâhil olmak üzere çeşitli kaynaklardan gelen bilgi ve önerilere rağmen, İndira başbakanlık muhafızları arasındaki Sihleri uzaklaştırmayı kabul etmemiştir. Mavi Yıldız harekâtından yaklaşık dört ay sonra, 31 Ekim 1984 sabahı, başbakanlık konutunda Sih dinine mensup iki muhafızı kadro silahlarıyla İndira'ya suikast düzenlemişlerdir. Yakın mesafeden yaklaşık 30 kadar kurşunla vurulan İndira hayatını kaybetmiştir. Olayın hemen ardından ülke genelinde ayaklanmalar çıkmış ve öfkeli halk tarafından pek çok Sih saldırıya uğramıştır. (Smith, 1984).

\section{GRİ ALANLAR}

İndira'nın yaşam öyküsünde yoruma ve tartışmaya fazlasıyla açık üç temel gri alan göze çarpmaktadır. Birincisi, 1975 yılında ilan edilen olağanüstü haldir. İndira iktidarına ilişkin en çok tartışılan konu olan olağanüstü hal dönemi (1975-1977) ona yönelik olumsuz eleştirilerin odağı olmaktadır. Bu dönemle ilgili somut manzara, olağanüstü hal döneminin sonundaki seçimlerde İndira Gandi ve partisinin birkaç yıllık geçici bir süre için dahi olsa iktidarı kaybetmiş olduğudur.

Olağanüstü hal dönemine ilişkin değerlendirmelerde bakış açısı belirleyici olmaktadır ve çeşitlilik söz konusudur. Bu çalışmanın kaynakçasında yer alan eserlerin çoğunda da mezkûr konuya değinilmekte ve tartışmalara yer verilmektedir. Olağanüstü 
hal süresince önemli inkılaplara imza atılmış olmasına rağmen nüfus planlaması kapsamında zorla kısırlaştırmalar yapıldığına dair iddialar da mevcuttur ancak bu çalışma hazırlanırken zorla kısırlaştırmaların gerçek olduğuna dair konuyla ilgili somut ve güvenilir bir kaynağa rastlanılmamıştır. Doğum kontrol yöntemleri arasında kısırlaştırma da uygulandığı literatürde yer alırken, kısırlaştırma ameliyatlarının parasal olarak teşvik edildiği bilinmekle birlikte zorla uygulandığ 1 kısmı şüphelidir. Yine bu dönemde, 1971 seçimleriyle ilgili yargı kararına İndira'nın saygı göstermediği veya demokrasiye aykırı hareket ettiği de öne sürülmektedir. Bununla birlikte söz konusu yargı kararının hükmedilen yaptırımı bakımından aşırı olup olmadığına ilişkin de literatürde tartışmalar vardır ${ }^{17}$.

İkincisi, yetiştiği ortamdır. Çocukluğundan itibaren daha erken yaşlarda Hindistan'ın ve Dünya'nın pek çok yerini görmüş olmasının, onun deneyim ve birikim bakımından zengin bir alt yapıya sahip olmasını sağladığı düşünülebilir. Pek çok ülkede ve pek çok okulda aldığı eğitim de onun farklı kültürlere vâkıf, çok yönlü bir insan olmasına katkı sağlamış olabilir. Erken yaşlardan itibaren karşılaşılan sosyal çevreye ilişkin bu tarz çeşitlilikler kişisel gelişim bakımından bir firsat arz ettiği gibi bir risk de arz etmektedir. İlk gençliğini sürekli değişen ortamlarda ve farklı çevrelerde yaşaması onun istikrarlı bir sosyal çevreden mahrum kaldığına da işaret etmektedir. Yetiştiği ortamın onun üzerinde yaptığı olumlu ve olumsuz etkiler geniş bir çerçevede tartışmaya açıktır.

Üçüncü gri alan ise evliliğidir. Aile hayatı bakımından eşiyle ilişkisi ve evliliğine ilişkin de çok farklı değerlendirme ve yorumlar vardır. İlişkilerinin niteliği ve karmaşıklığına dair farklı değerlendirmeler olduğu gibi, bunlara dair öne sürülen iddialarda farklı delil veya dayanaklar gündeme getirilmektedir. Bu çalışmanın konusu olmamakla birlikte İndira'nın eşi Firuze'nin biyografisi hakkında da ciddi belirsizlik ve

${ }^{17}$ Bir önceki bölümde verilmiş olmakla birlikte, başlıca kaynaklar için bkz. Palmer, 1976; Noorani, 2008; Somjee, 1977. 


\section{M.Y. ÇİÇEKLİ}

tartışmalar vardır. Özellikle kişiliği, etnik kökeni, dini bağları ve çalışmalarına ilişkin unsurlar hakkında belirsizlikler ve tartışmalar vardır.

\section{DEĞERLENDİRME}

1964'te ilk kez bakan olan İndira'nın vakur, kararlı ve kişilikli duruşu çevresindekileri etkilemiştir. "Gerçekten öyle miydi, yoksa öyle görünmeye mi çalışıyordu?" sorusu bir muamma olsa da, son anına kadar bu duruşundan taviz vermemiştir. Önceliklerini kişisel menfaatlere değil, toplumsal menfaat tahayyülüne bağlamış olduğu görülmektedir. Ahlaken de buna paralel bir duruşu vardır. İnkılapları gerektiğinde sert tutumlarla desteklerken, siyasal iktidarını teminat altına almak için bu ölçekte sert yaklaşımlara girmediği görülmektedir. Köklü inkılap hareketlerine girmekten kaçınmamış, ancak seçimlerde yenilgi aldığında da emekleme aşamasındaki Hindistan demokrasisinin kırılganlığına zarar vermekten kaçınarak sükûnetle koltuğunu devretmiştir.

Yaşamı boyunca karşılaştığı zorluklarda yeri geldiğinde aldığı fedakârca kararlar ve yeri geldiğinde kişisel arzulardansa ülke menfaatlerini dikkate alması önem arz etmektedir. Eşinin siyasal çalışmaları nedeniyle bulunduğu ili bırakıp başkente gelmesi mümkün değilken, babasının Başbakanlık koltuğundaki çalışmaları desteklemek üzere başkente taşınmıştır ve bu ayrılık eşi milletvekili seçilip başkente gelene kadar devam etmiştir. İki küçük çocuğu ve uzun süreli tutkulu aşkı olan bir çift için bu süreç ancak iki tarafin da idealist yurtsever siyasal kimlikleri göz önünde bulundurulduğunda anlaşılabilir.

Zaman zaman çevresinde yolsuzluk iddiaları yer almış olsa da, bu çalışmanın hazırlıkları sırasında literatürde; 1975'teki yargı kararına konu olan unsurlar dışında şahsına ait ispatlanmış bir yolsuzluğa rastlanılmamıştır. Söylem ve eylemlerinde fevkalade yurtsever ve halkçı olduğu görülen İndira'nın şahsi serveti lehine yolsuzluklara bulaşmamış olması, hayatı ve mücadelesinde istikrarlı olduğuna delalet etmektedir. 
Hindistan toplumsal yaşamında büyük belirleyiciliği ve önemi olan kast sistemi karşısında, toplumsal olarak dezavantajlı konumda bulunan tabakalardaki insanlarla yakından ilgilenmesi ve onlarla birlikte olabilmesi Hindistan demokrasisinin ve yurttaşlık kimliğinin güçlenmesine olumlu etkide bulunmuş olmalıdır. Kendisi üst bir kasttan geldiği halde, kendisine göre daha alt bir kasta mensup ve geleneksel kalıplar çerçevesinde düşünüldüğünde evlenmemesi gereken bir erkekle evlenmiştir. Yoksullukla mücadeleye ve toplumun ezilen kesimlerinin sorunlarına verdiği önem de göz önünde bulundurulursa bu deliller onu halkçı olarak tanımlamak için kullanılabilir. Şahsi geçmişi dikkate alındığında yalnızca kendisinin değil, tüm akrabalarının da menfaatine uygun düşen üst kastların avantajlı ve ayrıcalıklı konumunu güçlendirmek veya en azından korumak yerine, bir başka deyişle kendisinin ve çevresinin menfaatleri yerine; alt kastların hatta toplumsal olarak en altta yer alanların sorunlarını önemseyerek bunlarla uğraşmış olması, onun yozlaşmış bir lider olmadığının göstergelerinden biridir. Bu tablo da onun, eşitsizliği ne derecede merkezi bir sorun olarak gördüğünün ve bu çerçevede içine doğduğu toplumun tabuları karşısında modern düşünce kalıpları içinde ne ölçüde yoğrulduğunun ifadesi olarak okunabilir. Kaldı ki Hindistan gibi eşitsizliğin geleneklerle kutsandığı bir toplumda geleneksel kalıpları zorlamak, var olan eşitsizlik kalıplarından (kast sisteminden) menfaati olan grup ve bireylerin elbette tepkisini ve düşmanlığını kazanacaktır. ${ }^{18}$

Hindistan'ın zenginliğinin tekrar Hindistan'ın eline geçmesi ve refahın halka dağıtılması için yaptığı devletleştirmeler son derece büyük çaplı ve önemlidir. Yine başlıca projelerin de devlet eliyle yürütülmüş olması onun devletçi uygulamaları işlevsel bir araç olarak kullandığını göstermiştir. Bu devletçilik uygulamaları siyasal bir tercih olarak görülse dahi aslında uygulamaların önemli ölçüde zaruretten

18 Modernite düşüncesi Shmuel Noah Eisenstadt tarafından bir başkaldırı olarak tanımlanmaktadır ki bu da İ. Gandi’de karşılık bulmaktadır. 


\section{M.Y. Ç̇ÇEKLİ}

kaynaklandığı anlaşılmaktadır. ${ }^{19}$

İndira, Hindistan'ın güncel sorunlarını ve bir takım yapısal sorunlarını iyileştirebilse bile önemli bazı yapısal sorunları çözüme kavuşturamamıştır. İktidarı boyunca Pakistan ile Hindistan arasında irili ufaklı pek çok silahlı çatışma yaşanmıştır. Pakistan ve Hindistan arasındaki sınır ihtilaflarına barışçı1 bir çözüm üretememiş ve bu sorunları kendisinden sonra gelecek iktidarlara miras bırakmıştır. Ülkesinde farklı etnik ve dinsel gruplar arasındaki çatışmaları engellemeye çalışsa da nihai bir son verememiştir $^{20}$. Çin Halk Cumhuriyeti dişındaki komşularından daha güçlü bir ülke olan Hindistan, bu konumundan dolayı komşularının şüpheyle yaklaştığı bir ülke olmuştur.

Ülkesinde karşılaştı̆g 1 en önemli toplumsal sorunlardan biri, kendi yaşamına dahi mâl olan dinsel ayrılık ve çatışmalar konusudur. İndira için dinsel ayrılıklar ülkenin önünde bir engeldir ve bunların aşılması gerekir. Hindistan halkının farklı dinsel kimliklerinin yurttaşlar arasında ayrım yaratmamasını istemektedir. Böylece yurttaşlık kimliğinin cemaat kimliğinin önünde yer almasını istemekte, laikliği önemsemektedir. $\mathrm{Bu}$ da onun ne ölçüde modern düşünce yapısı içinde hareket ettiğini gösteren bir başka unsurdur.

Siyasal çalışmaları boyunca üzerinden çıkarmadığ 1 geleneksel kıyafetleri ve halkla iç içe olması, samimi ve halktan davranışları ve halkçı uygulamaları onun alamet-i farikasıdır. Has bir Hint olan Babası Hintçe’yi İngiliz aksanıyla konuşsa da, annesinden bir miras olarak Hintçeyi halk ağzıyla konuşabilmesi kitlelerle

19 Devletçilik uygulaması gerçekten de 2. Dünya Savaşı sonrasında sömürgecilikten kurtulup bağımsızlığını kazanan 3. Dünya Ülkeleri için kapitalizm ve sosyalizm dışında üçüncü kalkınma yolu olarak görülüp uygulanmıştır ve burada sayılanlar onun iyi bir örneğidir.

${ }^{20}$ Eşit haklara dayalı eşit vatandaşlık kimliği inşa etme gayreti dışarıdan bakan gözlemcilere adil bir çözüm olarak görünse de uygulamada gelenek, hizipçilik ve önyargılar gibi cevval hasımlarla karşı karşıya kalmıştır. 


\section{Dokuz Eylül Üniversitesi İktisadi ve İdari Bilimler Fakültesi}

bütünleşmek bakımından İndira'ya üstünlük sağlamıştır. Onun halkçılık anlayışının içinde kadınların da özel bir yeri olduğu göz ardı edilmemelidir.

Özel olarak dikkat çekilmesi gereken bir nokta da Sih meselesidir. Ayrılıkçı Sihlerle sert bir şekilde mücadele ederken yakın koruması olan Sihleri uzaklaştırmaması dikkate değerdir. Bu durum onun genel olarak Sihlere karşı değil, yalnızca ayrılıkçı Sihlere karşı tavır aldığını göstermektedir. Bir yandan devlet otoritesine meydan okuyan ayrılıkçı Sihlere karşı aşırıya kaçma noktasına dahi varan sert bir mücadele yürütürken diğer yandan yakın korumaları içindeki Sihlere karşı güvensizlik göstererek uzaklaştırma gereği duymaması ve ihtiyaten dahi böyle bir tedbir almaması onun eşit vatandaşlık temelinde hangi kökene ait olursa olsun halkına güvendiğini gösterir. Ne yazık ki bu güveninin çok kötü bir sonucu olmuş, ayrıllıçı Sihlerle mücadele sirasında mukaddes bir mekânda ölen ve zarar gören sivillerin intikamını almak isteyen yakın koruması Sihler tarafından suikasta uğramış ve hayatını kaybetmiștir.

Bağımsızlık sonrası İndira'nın tutum ve icraatlarına bakıldığında istikrarlı bir çizgi içinde; halkçı, milliyetçi, devletçi, laik, cumhuriyetçi ve yenilikçi öğeler göze çarpmaktadır. İndira'nın yaklaşımları her zaman halkçı olmuştur. Geniş halk kitlelerinin sorunlarını seçkinlerden daha çok dikkate almıştır ve toplumun büyük kısmını oluşturan sosyoekonomik olarak alt tabakalardaki insanları önemsemiştir. Milliyetçi ve devletçi yaklaşımlarıyla maliye, iktisat, tarım, milli savunma gibi her alanda ülkesinin kendi ayakları üzerinde durabilmesini arzulamıştır. Elbette Hindistan gibi çeşitliliğin her biçiminin var olduğu bir ülkede İndira'nın milliyetçilik anlayışı ırksal değildir, yurt ve yurttaşlık kavramlarına dayanmaktadır. Öte yandan İndira, herhangi bir dini yaklaşımın iktidarı tesir altına almamasını ve halkın ahenkli bir birlik oluşturmasını arzulamaktadır. Halkının dinsel ayrım ve kavgalarla bölünmesinden rahatsızlık duyması, Hinduların çoğunlukta olduğu ülkesine göç eden Müslümanlara haklarını verirken ayrıcalık isteyen Sih'lere izin vermemesi, "Hindistanlılık" üzerinde 


\section{M.Y. ÇİÇEKLİ}

birleşen bir yurttaşl1k anlayışı kurmak istemesi onun laik, eşitlikçi ve çoğulcu bir siyasal tahayyülü olduğunu gösterir. Bu tahayyüle uygun olarak adeta bir ulus devlet inşa etmek istemektedir. İndira'nın egemenliğin kaynağını halka dayandıran anlayışı, parti çalışmalarına verdiği önem ve seçimlerle göreve gelip seçimlerle koltuğunu bırakması, gerektiğinde yürüttüğü yenilikçi çalışmaların gerçekleşmesi için sert tavırlar almasıyla birleştiğinde manzara onun liberal bir demokrattan çok inkılapçı bir cumhuriyetçi olduğunu gösterir.

Bağımsızlık mücadelesi dönemindeki çabalarından kullandığı dile ve siyasal yaşamındaki geleneksel giyim tarzına kadar milli kimliğe dayanan bir siyasal tutumu yaşam biçimi haline getirdiği görülmektedir. Kimlik siyaseti bakımından sergilediği, bireylerin etnik veya dinsel kimliklerinin tesis edilmeye çalışılan eşit vatandaşlık hukuku karşısında adeta ikinci plana ve özel yaşama itilmesi gayreti aynı zamanda azınlıkların ve göçmenlerin toplumsal konumlarını iyileştirme ve eşit hak sahibi yapma gayreti de içermektedir. Gençliğinde Avrupa'da bulunduğu dönem milliyetçiliğin değil; ırkçılık, Nazizm ve faşizmin yükseldiği bir dönemdir. Buna rağmen ülkesine dönerken yanında ırkçılık veya ötekileştirici bir milliyetçilik getirmemiştir ${ }^{21}$.

Yetiştiği ortam bakımından karşılaştığı coğrafi, sosyal, kültürel ve kurumsal çeşitliliklerden faydalanabilmiş görünmektedir. Çok yönlü kişiliği bu çeşitliliklerden faydalanmış olmasıyla ilişkilendirilebilirse de, bir takım eylemlerini bu temelle ilişkilendirmek; bu savların sınanması mümkün olmadığından ancak öznel bir değerlendirme olacaktır. İndira'nın, zengin ailesinin güvenli sınırları dışında, kişisel refah ve sefahâttense milli mesele ve ulusal menfaatleri öne çıkaran hayat tercihleri (iktidara yükselmesi bir tarafa bırakılırsa) adeta taht ve sarayı bırakıp aydınlanan ve

\footnotetext{
${ }^{21}$ Burada, Hindistan gibi büyük ve engin bir çeşitliliğin var olduğu bir ülkede yaşamanın ve erken yaşlarında İsviçre ve İngiltere gibi farklı kültürlerin vatandaşlık kimliği altında bir araya geldiği ülkeleri gözlemlemiş olmasının etkisi olmuş olabilir. Öte yandan İsviçre ve (bilhassa 1939 sonuna kadar) İngiltere Nazizm'in adeta sempati ile karşılandığı ülkelerdir.
} 


\section{Dokuz Eylül Üniversitesi İktisadi ve İdari Bilimler Fakültesi}

Cilt:33, Sayl:2, Yll:2018, ss.411-434

insanları aydınlatmaya ömrünü adayan (Gotama) Buda'nın ${ }^{22}$ yaşamını çağrıştırmaktadır.

\section{SONUÇ}

İndira Priyadarşini Gandi, küçük yaşlardan itibaren yetiştiği ailenin duruşuna paralel olarak, bir Hint milliyetçisi olarak hayatını sürdürmüştür. Davası uğruna mücadele etmiş, hapis yatmış ve hayatını inandığı davaya vakfetmiştir. Denilebilir ki İndira'nın hayatı bir milliyetçinin mücadelesinden ibarettir. Önce bağımsızlık için, ardından ülkesinin yükselmesi için mücadele etmiştir. Bütün hayatı boyunca önceliği ülkesi için hassas gördüğü meselelere vermiştir. Siyasal çalışmalarının yanında başka hiçbir işle uğraşmamıştır. Adeta bir annenin özveri ve tutkuyla çocuğuyla ilgilendiği gibi ülkesiyle ilgilendiği söylenebilir. İndira Gandi, BBC'nin yukarıda zikredilen anketinde aldığı unvana yakışır bir yaşam sürmüştür. O "bin y1lın en büyük kadını" unvanını tam anlamıla hak etmektedir ${ }^{23}$.

Hem varsıl bir aileden gelip, hem halk için çalışan; hem halkını hem de doğayı sevip korumak isteyen; kişisel menfaatlerini öncelikleri arasına almamış, tarım ve sanayii arasında kesin bir tercih yapmadan ülkesini kalkındırmaya çalışan, adeta ülkesinin tüm sorun ve sıkıntılarını dert edinen idealist bir liderdir ${ }^{24}$. Davası uğruna hapse girmiş bir bağımsızlık savaşçısı, bir âşık, bir anne, babasının kızı ve ülkesinin başbakanı olarak son derece yorucu bir yaşamı olmuştur. Yaşamı boyunca zor tercihlerle ve güçlüklerle karşı karşıya kalmış fakat hiç yılmamıştır. İlham verici bir yaşam sürdüğü, ilham verici bir kadın olduğu teslim edilmelidir.

Ülkesindeki yapısal sorunlarla mücadele etmiş ve bu sorunların bazılarına çözümler

\footnotetext{
${ }^{22}$ Gotama Buda; öğretileriyle Budizm dininin kurucusu sayılan ve milattan önce dört ila altıncı yüzyıllarda Hindistan'da yaşadığı tahmin edilen büyük bir filozof ve tarihsel kişiliktir.

${ }^{23}$ Bakınız: bu makalenin "Giriş" bölümü.

${ }^{24}$ Siyasal tutum ve tercihlerinin doğu ve batı bloğunun dışındaki üçüncü dünya ülkeleri arasındaki konumu ve ne derece özgün olduğu, ayrıca doğu ve batı ile ilişkilerinin ayrıntıları ayrıca incelenmeye değerdir.
} 


\section{M.Y. Ç̇ÇEKLİ}

üretebilmiştir. Öte yandan kalıcı çözüm bulamadığı sorunlar da vardır. Son tahlilde İndira'nın iktidarında Hindistan önemli mesafeler kat etmiştir. ÇHC dışında bölgesindeki en büyük güç olarak kendini ispatlamıştır ve bölgesel sorunları kendi lehine çözümleyebilmiştir. Kişisel menfaat veya zenginliği için çalışmamış ve aynı zamanda önemli başarılara ulaşmış tam bir "devlet adamıdır"25.

İndira'nın milliyetçi politikalarındaki en göze çarpan unsur, kadınlara, yoksullara, toplumda geri kalmış/düşük mevkilerdeki bireylere öncelik vermesi ve onların durumlarını iyileştirmek için adımlar atmış olmasıdır. Bu çerçevede onun milliyetçi politikaları halkçı ve feminist bir gündemi de içermektedir.

İndira Priyadarşini Gandi, 20. Yüzyıla hatta milattan sonra İkinci Binyıla mâl olmuş önemli bir kadındır. Yaşam öyküsü bağımsız Hindistan'ın doğuşuna paralellik göstermektedir. Soğuk Savaşın ortasında, bağımsızlığı yeni kazanmış dev bir ülkenin başında bu ülkeyi yükseltmek için büyük bir mücadele vermiştir. Onun yaşam öyküsü bağımsızlıkçı, milliyetçi, halkçı, devletçi, laik, cumhuriyetçi ve yenilikçi bir siyasal mücadele olarak özetlenebilir. O, tüm günahları ve sevaplarıyla birlikte Hindistan bağımsızlığının (Gotama) Buda’sıdır.

\section{KAYNAKÇA}

AHMED, I. (1999), State, Nation, and Ethnicity in Contemporary South Asia. Octopus Publishing Group Limited, London. s. 130.

AXELROD-CONTRADA, J. (1999), "Indira Gandhi Mother to India" Women Who $\begin{array}{llll}\text { Led Nations, The } & \text { Oliver } & \text { Press, } & \text { s. }\end{array}$ (http://books.google.com.tr/books?id=Hfyh6znd9d4C erişim 10.12.2012)

BBC News: May/27 (yayın yılsı), "Light goes out in India as Nehru dies.” BBC On This

Day.

${ }^{25}$ Burada "devlet adamı" sözüyle yapılmak istenen vurgu toplumsal cinsiyet kalıplarına değil, kişisel nitelikleredir. İndira GANDİ bizzatihi toplumsal cinsiyet kalıplarını aşmış bir kadın figürüdür. 
Dokuz Eylül Üniversitesi İktisadi ve İdari Bilimler Fakültesi

Cilt:33, Sayl:2, Yll:2018, ss.411-434

(http://news.bbc.co.uk/onthisday/hi/dates/stories/may/27/newsid_3690000/3690019.st

m erişim 20.12.2012)

BBC News (1998). "India's ruling dynasty" World: Analysis, BBC News, 12.01.1998 (http://news.bbc.co.uk/2/hi/special_report/1998/india_elections/46883.stm erişim 20.12.2012)

BBC News (1999). "Indira Gandhi 'greatest woman' " BBC News Online, 01.12.1999 (http://news.bbc.co.uk/2/hi/543743.stm erişim 20.12.2012)

BRAR, K. S. (1993), Operation Blue Star: True Story. South Asia Books.

DAS, S. (2001), “The Nehru Years in Indian Politics” Edinburgh Papers In South Asian Studies, Number 16.

DASH, L. N. (2000), World bank and economic development of India. APH Publishing. ～(http://books.google.com.tr/books?id=rRWDxpHcBHoC erişim 10.12.2012)

DOMMERMUTH-COSTA, C. (2001), Indira Gandhi: Daughter of India, Lerner Group, Minneapolis, (http://books.google.com.tr/books?isbn=0822549638 erişim 10.12.2012)

FRANK, K, (2002) Indira: The Life of Indira Nehru Gandhi, Houghton Mifflin Harcourt, Boston.

GANDHI, İ.; EMMANUEL P. (ed.), (2013) My Truth, Orient Paperbacks, New Delhi, (ilk bask1 1981), (http://books.google.com.tr/books?id=uWoTAAAAMAAJ erişim 10.12.2012)

GUPTE, P. (2012), Mother India: A Political Biography of Indira Gandhi. Penguin Books India. s. 5.

GUPTA, U. N. (2003), Indian Parliamentary Democracy. Atlantic Publishers \& Distributors. s. 121. 


\section{M.Y. ÇİÇEKLİ}

HEITZMAN, J. ; WORDEN, R. L. (1995), (ed.). India: A Country Study. Federal Research Division, Washington. (http://countrystudies.us/india erişim 25.12.2012)

IPU (1971) “India 1971” PARLINE, Inter Parliamentary Union, (http://www.ipu.org/parline-e/reports/arc/INDIA_1971_E.PDF erişim 20.12.2012)

IPU (1977) “India 1977” PARLINE, Inter Parliamentary Union, (http://www.ipu.org/parline-e/reports/arc/INDIA_1977_E.PDF erişim 20.12.2012)

IPU (1980) “India 1980” PARLINE, Inter Parliamentary Union, (http://www.ipu.org/parline-e/reports/arc/INDIA_1980_E.PDF erişim 20.12.2012)

JAFFRELOT, C. (2003), India's Silent Revolution: The Rise of the Lower Castes in North India. C. Hurst \& Co. Publishers. 2003. s. 131-142.

KELLY, D.; DAVID, A. (2010), Ramkishen S. Raj, Gillian H. L. Goh. Managing Globalisation: Lessons from China And India. World Scientific.

KULKE, H. ; DIETMAR, R. (2004), A History of India. Routledge. New York. s. 359 (http://books.google.com.tr/books?id=TPVq3ykHyH4C erişim 15.12.2012)

LYON, P. (2008), Conflict Between India and Pakistan: An Encyclopedia. Santa Barbara: ABC-CLIO. ISBN 978-1576077122.

MARTY, M. E.; APPLEBY R. (2004), Fundamentalisms Comprehended. University of Chicago Press. s. 454.

MURALIDHARAN, D. (2009), Modern Banking: Theory And Practice. PHI Learning Yeni Delhi. s. 4. (http://books.google.com.tr/books?id=RX_dLGtIE3AC erişim 14.12.2012)

NAYAK, P.; BISHWANATH, G.; PRADEEP, A. (2010), India's Economy and Growth. SAGE Publications. s. 8-9.

NEHRU, J. (1929) Letters from a father to his daughter, being a brief account of the early days of the world, written for children. Allahabad Law Journal Press, 
Allahabad. (https://www.worldcat.org/title/letters-from-a-father-to-his-daughter-beinga-brief-account-of-the-early-days-of-the-world-written-for-children/oclc/47215515 erişim 20.12.2012)

NEHRU, J. (1934) Glimpses of World History. Kitabistan, Allahabad. https://www.worldcat.org/title/glimpses-of-world-history/oclc/463743552 erişim 20.12.2012)

NOORANI, A.G. (2008), "Justice with a fine balance" Frontline, Cilt 25, Say1 08, Nisan 2008 (http://www.frontlineonnet.com/f12508/stories/20080425250808200.htm erişim 25.12.2012)

OPFELL, O. S. (1993), Women prime ministers and presidents. McFarland Publishing.

PALMER, N. D. (1976), "India in 1975: Democracy in Eclipse", Asian Survey, cilt 16, Sayı 5, 1976, California (http://www.jstor.org/discover/10.2307/2643138 erişim 10.12.2012)

QUERESHI, H. A. (2002), The 1971 Indo-Pak War, A Soldiers Narrative, Oxford University Press.

RACIOPPI, L. (1994), Soviet Policy Towards South Asia since 1970. Cambridge University Press. s. 65.

READ, A.; FISHER, D. (1999), The Proudest Day: India's Long Road to Independence. W. W. Norton \& Company. s. 459-460.

ROMEIN, J. (1962), The Asian Century: a History of Modern Nationalism in Asia. $\begin{array}{lllll}\text { University of } & \text { California }\end{array}$ (http://books.google.com.tr/books?id=OXaIQZMevjcC erişim 25.12.2012)

ROSSER, J. B. ; MARINA V. R. (2004), Comparative Economics in Transforming the World Economy. MIT Press. s. 468-470 


\section{M.Y. Ç̇ÇEKLİ}

SARKAR, S.; SARKAR T. (2008), Women and Social Reform in Modern India. Indiana University Press. s. 489-490 vd.

SMITH, W. E. (1984), "Indira Gandhi: Death in the Garden", Time Dergisi, 12 Kasim 1984. (http://www.time.com/time/magazine/article/0,9171,926929-2,00.html erişim 10.12.2012)

SOMERVILL, B. A. (2007), Indira Gandhi: Political Leader in India, Compass Point Books, Minneapolis.

SOMJEE, A. H, (1977), "Indian Democracy at Crossroads", Contrubituons To Asian Studies, E.J.BRILL, Leiden, Netherlands (http://books.google.com.tr/books?id=VRMVAAAAIAAJ erişim 15.12.2012)

UR, N. S. (2009), Allahabad; Where the Rivers Meet, Antique Collectors Club Limited, (http://books.google.com.tr/books?id=IeFiPgAACAAJ erişim 25.12.2012)

https:// www.badmintonschool.co.uk/2372/oba (erişim 10.12.2012) "Badminton School OBA" Badminton School Bristol.

http://www.guardian.co.uk/theguardian/series/greatspeeches (erişim 20.12.2012) "Greatest Speeches of the 20th Century" The Guardian.

http://nuclearweaponarchive.org/India/IndiaSmiling.html (erişim 28.12.2012) “India's Nuclear Weapons Program, Smiling Buddha: 1974” Nuclear Weapon Archive, 2001.

http://www.ox.ac.uk/media/news_releases_for_journalists/100422_1.html (erişim 28.12.2012) "Exhibit Celebrates 120 Years of South Asians at Oxford". University of Oxford, 22 April 2010.

http://visvabharati.ac.in (erişim 28.12.2012) Visva-Bharati University. 